\begin{tabular}{|c|l|}
\hline Title & Reversal of ice motion during the outburst of a glacier-dammed lake on Gornergletscher, Switzerland \\
\hline Author(s) & Sugiyama, Shin; Bauder, A ndreas; Weiss, Patrik; Funk, Martin \\
\hline Citation & $\begin{array}{l}\text { Journal of Glaciology, 53(181), 172-180 } \\
\text { https:/doi.org/L0.3189/172756507782202847 }\end{array}$ \\
\hline Issue Date & 2007-03 \\
\hline Doc URL & http://hdl.handle.net/2115/34783 \\
\hline Rights & ○ 2007 International Glaciological Society \\
\hline Type & article \\
\hline File Information & sugiyama_others_2007_jg.pdf \\
\hline
\end{tabular}

Instructions for use 


\title{
Reversal of ice motion during the outburst of a glacier-dammed lake on Gornergletscher, Switzerland
}

\author{
Shin SUGIYAMA, ${ }^{1,2}$ Andreas BAUDER, ${ }^{2}$ Patrik WEISS, ${ }^{2}$ Martin FUNK ${ }^{2}$ \\ ${ }^{1}$ Institute of Low Temperature Science, Hokkaido University, Sapporo 060-0819, Japan \\ E-mail: sugishin@lowtem.hokudai.ac.jp \\ ${ }^{2}$ Versuchsanstalt für Wasserbau, Hydrologie und Glaziologie (VAW), Eidgenössische Technische Hochschule ETH Zentrum, \\ $\mathrm{CH}$-8092 Zürich, Switzerland
}

\begin{abstract}
During the outburst flood of a glacier-dammed lake on Gornergletscher, Switzerland, in July 2004, the drained lake water triggered anomalous glacier motion. At the onset of the outburst, the ice-flow direction in the vicinity of the lake became closer to the central flowline. When the lake discharge magnitude decreased, the flow direction altered such that the ice moved back to the azimuth of the initial motion. At one of the survey points, where the ice flows parallel to the central flowline, the ice accelerated along the pre-event flow direction followed by a $\mathbf{1 8 0}^{\circ}$ backward motion that lasted over 2 days. These observations indicate the impact of the lake outburst on the subglacial and englacial stress conditions; however, the reversal in the flow direction is difficult to explain by drawing on our current understanding of glacier mechanics. The timing and the timescale of the flow-direction changes suggest that the elastic glacier motion and its rebound played a role under the rapidly changing stress conditions, but the Young's modulus of ice is too large to cause the observed ice motion. Other processes, including basal separation and subglacial sediment deformation, are discussed as possible mechanisms for the reversal of the ice motion.
\end{abstract}

\section{INTRODUCTION}

The sudden drainage of a glacier-dammed lake provides a unique opportunity to study the influence of subglacial hydrological conditions on glacier dynamics. Since an enormous amount of lake water drains into the glacier bed within a short period, the glacier flow regime is expected to change dramatically during an outburst event due to the changing subglacial conditions. According to the diurnal flow variations and motion events observed in the alpine glaciers, a sudden water input into the bed enhances the basal ice motion by increasing the subglacial water pressure (e.g. Iken and Bindschadler, 1986; Naruse and others, 1992; Jansson, 1995; Sugiyama and Gudmundsson, 2004). The iceflow speed significantly increases as the pressure approaches the ice overburden pressure and the glacier sole decouples from the bed (e.g. Iverson and others, 1995, 1999; Fischer and Clarke, 2001). Since the water flux from a draining lake is generally much larger than the meltwater input, the lake drainage may cause flow changes that are not observable under the usual hydrological conditions. The study of glacier dynamics with a special emphasis on subglacial hydrology is of critical importance because the basal flow processes assume a key role, not only in small mountain glaciers, but also in fast-flowing ice streams on large ice sheets (e.g. Engelhardt and Kamb, 1998; Kamb, 2001). In addition to the general interest in the glacier dynamics, it is also important to study ice motion near a glacier-dammed lake because it plays an active role in the lake drainage process. The motion of an ice dam may control the water discharge from a lake; therefore, ice dynamics in the vicinity of the lake is crucial to understanding the triggering mechanism of the outburst.

Despite the critical importance and keen interest indicated above, few ice-flow measurements have been conducted during lake outburst events. This is because the prediction of an outburst is difficult. One successful measurement was carried out during the drainage of Hidden
Creek Lake at Kennicott Glacier, Alaska, USA, in 2000. Stake surveys on the ice dam suggested that a fault penetrating from the glacier surface to the bed caused a surface uplift before the drainage (Walder and others, 2005, 2006). Stake motion near the central flowline showed an increase in the flow speed accompanied by surface uplift, thereby suggesting enhanced basal sliding and subglacial cavity enlargement (Anderson and others, 2005). These measurements, together with the observations of subglacial hydrology and hydrochemistry (Anderson and others, 2003), provided important information for the study of the impact of the outburst on glacier dynamics. In Iceland, the ice surface motion of Skeiðarárjökull was continuously measured by a global positioning system (GPS) during the outburst event of Grímsvötn in 2004 (Roberts and others, 2005). A ten-fold increase in the horizontal flow speed and a decimeter-scale surface uplift were observed near the glacier terminus. The surface elevation permanently increased by $0.3 \mathrm{~m}$, representing a lasting impact of the flood on the glacier.

To better understand the dynamic response of a glacier to a lake outburst, we conducted an intensive field campaign on Gornergletscher, Switzerland, in 2004. The aim of the study was to obtain a comprehensive dataset describing the glacier dynamics and hydraulics during the outburst event of Gornersee, a glacier-dammed lake on Gornergletscher. During the outburst in July 2004, ice-flow measurements showed extraordinary ice motion triggered by the lake drainage. This paper reports the details of the ice-flow changes during the event and discusses possible mechanisms of the anomalous ice motion.

\section{FIELD MEASUREMENTS}

\section{Study site}

Gornergletscher is the second largest valley glacier system in the Swiss Alps, with a surface area of $68 \mathrm{~km}^{2}$ (Raymond and 

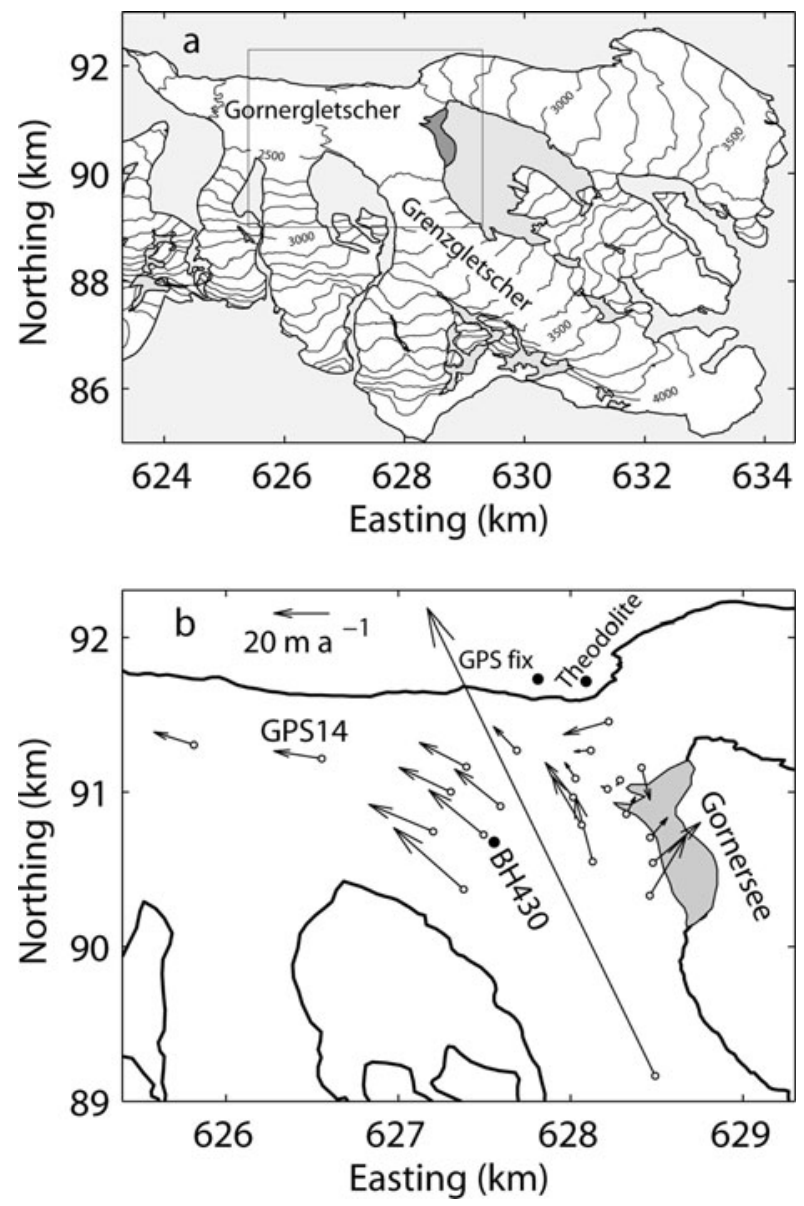

Fig. 1. (a) Map of Gornergletscher and Grenzgletscher with surface contour lines at intervals of $100 \mathrm{~m}$. The study area is indicated by the box. (b) Location of the GPS and theodolite survey stakes with annual flow vectors obtained for the period October 2003 to September 2004. The borehole drilling site is labeled $\mathrm{BH} 430$.

others, 2003). The upper part of the $12 \mathrm{~km}$ long main stream is named Grenzgletscher; it merges with Gornergletscher $\sim 5 \mathrm{~km}$ from the common terminus of the glacier system (Fig. 1a). Many investigations have been conducted at Gornergletscher with regard to glacier hydrology and ice dynamics (e.g. subglacial water-pressure measurements (Röthlisberger and others, 1979), hydrological study of glacier run-off (Collins, 1989) and combined measurements of subglacial hydrology and glacier dynamics (Iken and others, 1996)).

At the eastern margin of the confluence area of Gornergletscher and Grenzgletscher, a glacier-dammed lake named Gornersee forms in the spring; it collects snowmelt and drains every summer (Figs 1 and 2). The historical records of its formation and outburst date back to the 18th century (Huss and others, 2007). The lake water flows through the glacier for $5 \mathrm{~km}$ before it drains into the outlet river Gornera. The maximum ice thickness between the lake and the glacier snout is about $450 \mathrm{~m}$ according to an ice-penetrating radar survey carried out in 2004 (Huss, 2005). The volume of water stored in the lake before the outburst shows an annual variation. In 2004, the maximum water volume was estimated to be $4.0 \times 10^{6} \mathrm{~m}^{3}$ from the water level and the hypsometry of the lake floor, obtained by processing an aerial photograph taken after the lake was emptied (Huss and others, 2007).

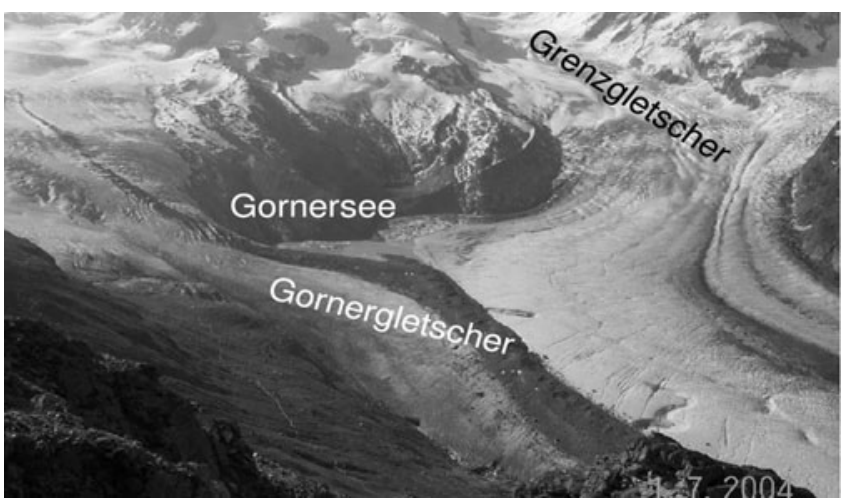

Fig. 2. The confluence area of Gornergletscher and Grenzgletscher, and Gornersee in the center of the photograph. The photograph was taken on 1 July 2004 from Gornergrat, the northern flank of Gornergletscher.

\section{Ice-flow measurements}

In order to measure the ice motion, aluminum stakes were installed in the glacier surface in October 2003, using either GPS or an automatically operated theodolite. The length of the stakes above the surface was maintained at less than $2 \mathrm{~m}$ to reduce the influence of wind on the survey accuracy. In addition to the high-frequency measurements described below, the stakes were surveyed with GPS in October 2003 and September 2004 to determine the annual flow speeds. The locations of the stakes and annual flow vectors are indicated in Figure $1 \mathrm{~b}$.

The three-dimensional positions of four of the stakes (GPS14, GPS24, GPS37 and GPS42) were surveyed by GPS receivers (Leica System 500) mounted on the top of the stakes (see Fig. 4 for the locations). From 18 June to 12 July 2004, the L1 and L2 phase signals from the GPS satellites were recorded eight times a day for 1 hour at regular 3 hour intervals. The GPS data were post-processed using Leica SKI-Pro software with reference data recorded by a receiver fixed on the bedrock at the glacier flank (Fig. 1b). The accuracy of the survey depends on the horizontal distance and the elevation difference from the reference station, satellite configuration and wind conditions. Control experiments and past measurements on glaciers provide an estimate of the positioning errors, 3 and $5 \mathrm{~mm}$ in the horizontal and vertical directions, respectively (Sugiyama and Gudmundsson, 2004).

Theodolite reflectors were mounted on the remaining stakes to survey the positions from the glacier flank. The theodolite installed on the bedrock (Fig. 1b) was automatically operated every hour from May to September 2004, unless operation was interrupted by weather conditions or equipment failure. The data obtained were corrected by surveying the reference reflectors fixed on the bedrock in the marginal vicinity. The errors in the measurement vary from several millimeters to centimeters, depending on the distance from the theodolite to the stakes (Gudmundsson and others, 2000).

The surface flow speed at each stake was calculated from the horizontal displacement after filtering the surveyed coordinates by kernel regression smoothing with adaptive plug-in bandwidth (Seifert and others, 1994). The opensource Fortran routine employed for this uses a filtering bandwidth determined to correspond to the estimated 


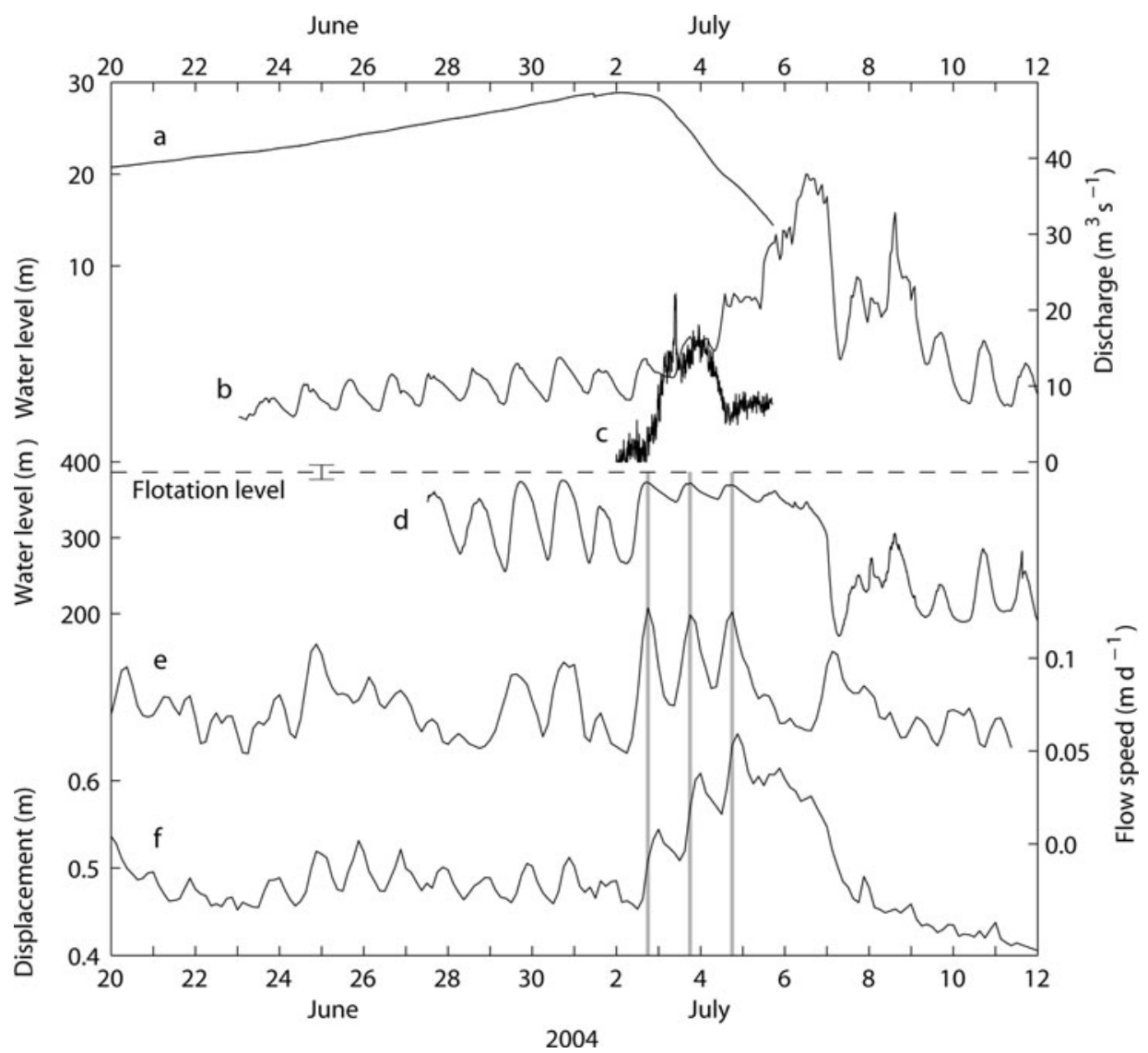

Fig. 3. Time series of (a) lake water level, (b) discharge from the glacier, (c) discharge from the lake, (d) water level in borehole $\mathrm{BH} 430$ and (e) horizontal flow speed and $(\mathrm{f})$ vertical displacement at GPS14. The vertical displacement is relative to the elevation at the beginning of the GPS survey on 15 April. The dashed line indicates the flotation water level at the borehole site with an error bar. The vertical gray lines show the correlation of the water level, flow speed and vertical displacement.

survey errors. The code is available at http://www.unizh.ch/ biostat/Software/kernf77.html.

\section{Hydrological measurements}

Measurement of lake level began in May 2004. A waterpressure transducer (Keller, PAA-36W) with an accuracy of $\pm 60 \mathrm{~Pa}$ was installed near the deepest point in the lake to record the water depth every $10 \mathrm{~min}$. The measurement was terminated when a floating ice block cut the sensor cable during the outburst on 5 July. The discharge from the lake for the period 2-5 July was computed from the change in water level and the hypsometry of the lake floor.

At about $1 \mathrm{~km}$ down-glacier from the lake, a borehole (BH430 in Fig. 1b) was drilled to the bed using the hot-water drilling technique. The ice thickness at the drilling site is $430 \pm 20 \mathrm{~m}$ according to the length of the hose used for the drilling and ice-penetrating radar survey. A vibrating wire pressure transducer (Geokon Model 4500) was installed in the borehole to measure the water pressure at intervals of $10 \mathrm{~min}$. The accuracy of the measurement was equivalent to a water level of $\pm 0.35 \mathrm{~m}$. Due to the uncertainty in the distance from the glacier bed to the sensor, the absolute value of the water level from the bed may have an error of up to $\pm 10 \mathrm{~m}$.

Water discharge from the glacier is measured by the Grande Dixence hydroelectric power company. The company operates a water intake system $\sim 1 \mathrm{~km}$ down the valley from the glacier terminus and measures the river discharge every hour.

\section{RESUITS}

\section{Formation and outburst of Gornersee in 2004}

In 2004 the lake began to form in mid-May. The lake filled with water extending over a surface area of $0.27 \mathrm{~km}^{2}$ by the end of June and the lake water began to flow over the ice surface on 1 July. The water level had increased steadily, showing no clear indication of water leakage until it suddenly dropped by $30 \mathrm{~cm}$ on 1 July (Fig. 3a). The $30 \mathrm{~cm}$ drop occurred within the 10 min recording interval of lake level measurements and could be observed by the formation of a strandline at the lake shore. This incident suggests the transfer of $\sim 8 \times 10^{4} \mathrm{~m}^{3}$ of water into the subglacial space prior to the main drainage.

The lake outburst began on 2 July and the water level dropped continuously until the lake emptied on 7 July. Although the water-level figure is available only until late in the evening on 5 July, the discharge from the lake indicates that nearly $70 \%$ of the stored water drained during the days from 3 to 5 July (Fig. 3c). Peak discharge from the lake occurred on 3 July, while discharge at the terminus peaked 3 days later on 6 July (Fig. 3b). In the latter half of the event, we observed that the water drained subglacially from the eastern margin of the glacier. However, after the event, we found several water channels (the diameters of which were of the order of a few meters) excavated into the ice at the lake floor (Weiss, 2005), indicating that a part of the water also drained englacially. 


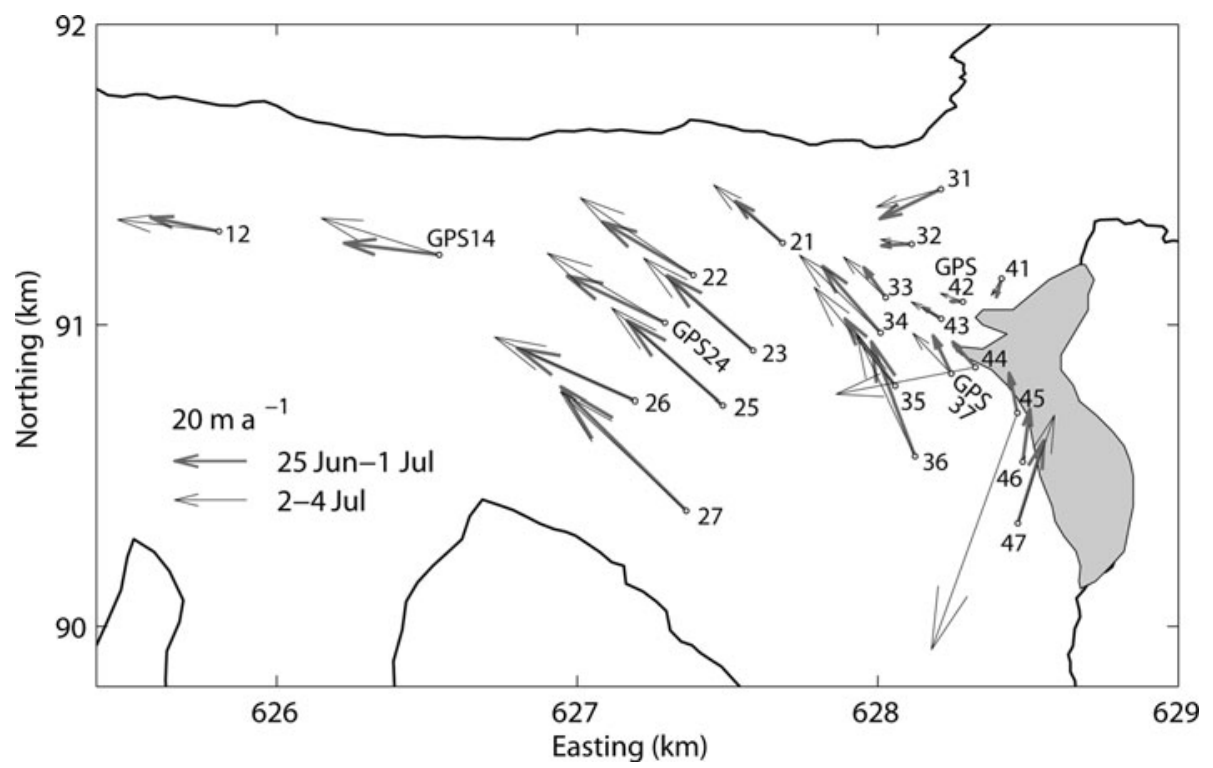

Fig. 4. Horizontal flow speed vectors before the lake outburst from 25 June to 1 July (gray bold) and during the first half of the outburst from 2 to 4 July (black thin).

During the outburst, the water level in borehole BH430 was consistently high and was close to the flotation level (Fig. 3d). In contrast to the large oscillations observed before the outburst, the magnitude of the diurnal variations is small, showing a clear influence of the drained lake water on the hydrological conditions underneath the borehole site. The water level dropped by $\sim 200 \mathrm{~m}$ on 7 July, corresponding to the decrease in the discharge from the glacier (Fig. 3b).

\section{Surface flow speed and uplift}

The horizontal flow speed and vertical displacement measured at GPS14 are plotted in Figure $3 \mathrm{e}$ and $\mathrm{f}$, for comparison with the hydrological data. From 2 to 4 July, during the drainage period, the flow speed shows clear diurnal variations (Fig. 3e) and the daily maxima in the evening coincide with peaks in the borehole water level (Fig. 3d). The mean speed during this period is $150 \%$ of the mean before the outburst $\left(0.063 \mathrm{~m} \mathrm{~d}^{-1}\right.$ for the period 24 June to 1 July). After 6 July, the flow speed and its variations are similar to those before the outburst. During the same period, the glacier surface lifted up diurnally by about $0.1 \mathrm{md}^{-1}$, resulting in a total uplift of $0.2 \mathrm{~m}$ over the 3 days (Fig. 3f). Hereafter, we use the term 'uplift' to refer simply to the upward vertical displacement by paying attention to the annual mean vertical speed, which is $2.5 \mathrm{~mm} \mathrm{~d}^{-1}$ at GPS14. The daily elevation peaks lagged several hours behind the borehole water-level peaks; thus, the maximum uplift rate corresponded to the maximum water level (Fig. 3d). The diurnal vertical motion had also been observed before drainage, but the elevation change did not accumulate because the daily uplift was cancelled out by the subsequent downward motion. The surface started to lower on 6 July and reached the same level as the pre-event elevation after 2 days. Similar elevation changes were observed at most of the other survey stakes.

The horizontal flow vectors during the first half of the outburst ( 2 to 4 July) are compared with those before the event (25 June to 1 July) in Figure 4. The surface speed increased and the flow direction changed at most of the stakes. Near the lake, the direction of the flow vectors during the first half of the event is more to the west, as indicated by the counterclockwise vector rotation at stakes 33-36 and GPS37, and the clockwise rotation at stakes 31, 32 and 41 and GPS42. In the lower reaches, the flow vectors are more to the north, as observed at stake 22, GPS14 and GPS24. In general, the glacier flow field became more parallel to the central flow direction at the confluence area (stakes 23, 25 and 27), which is dominated by the fast inflow from Grenzgletscher (see Fig. 1b).

Exceptionally large changes in the flow speed and direction were observed at stakes $44-46$ at the west shore of the lake. The ice motion accelerated towards the west at stake 44 and southwest at stake 45, whereas the flow speed became very small at stake 46 . At these three stakes, the upward vertical displacement during the outburst was in range $0.5-3.0 \mathrm{~m}$, one order of magnitude larger than at the other stakes (Weiss, 2005) and far different from the annual mean vertical motion at these stakes $\left(-5.9\right.$ to $\left.-1.4 \mathrm{~mm} \mathrm{~d}^{-1}\right)$. Since the glacier surface was heavily crevassed in this region, the huge uplift was probably a local response of the marginal ice to buoyancy force. We assume that englacial fractures acted as a hinge under the direct influence of the draining water, but details of the ice motion in the vicinity of the lake will be presented elsewhere.

\section{Reversal of ice motion}

Figure 4 shows the difference in the glacier flow field before and after the onset of the outburst. Moreover, during the drainage event continuous stake measurements showed complex flow-direction changes, hereafter referred to as the 'reversal of ice motion'. The southwest ice flow at GPS42 changed its direction to the northwest during the first half of the outburst (Fig. 5a). It then turned south on 4 July and moved south during the second half of the outburst until the stake returned to the azimuth of the pre-event ice motion. The flow direction returned to the southwest when the lake became empty. It appears that a transverse (northwestsoutheast) flow component was superimposed on the preevent flow direction (southwest) over the course of the outburst, and the transverse component reversed on 4 July. 


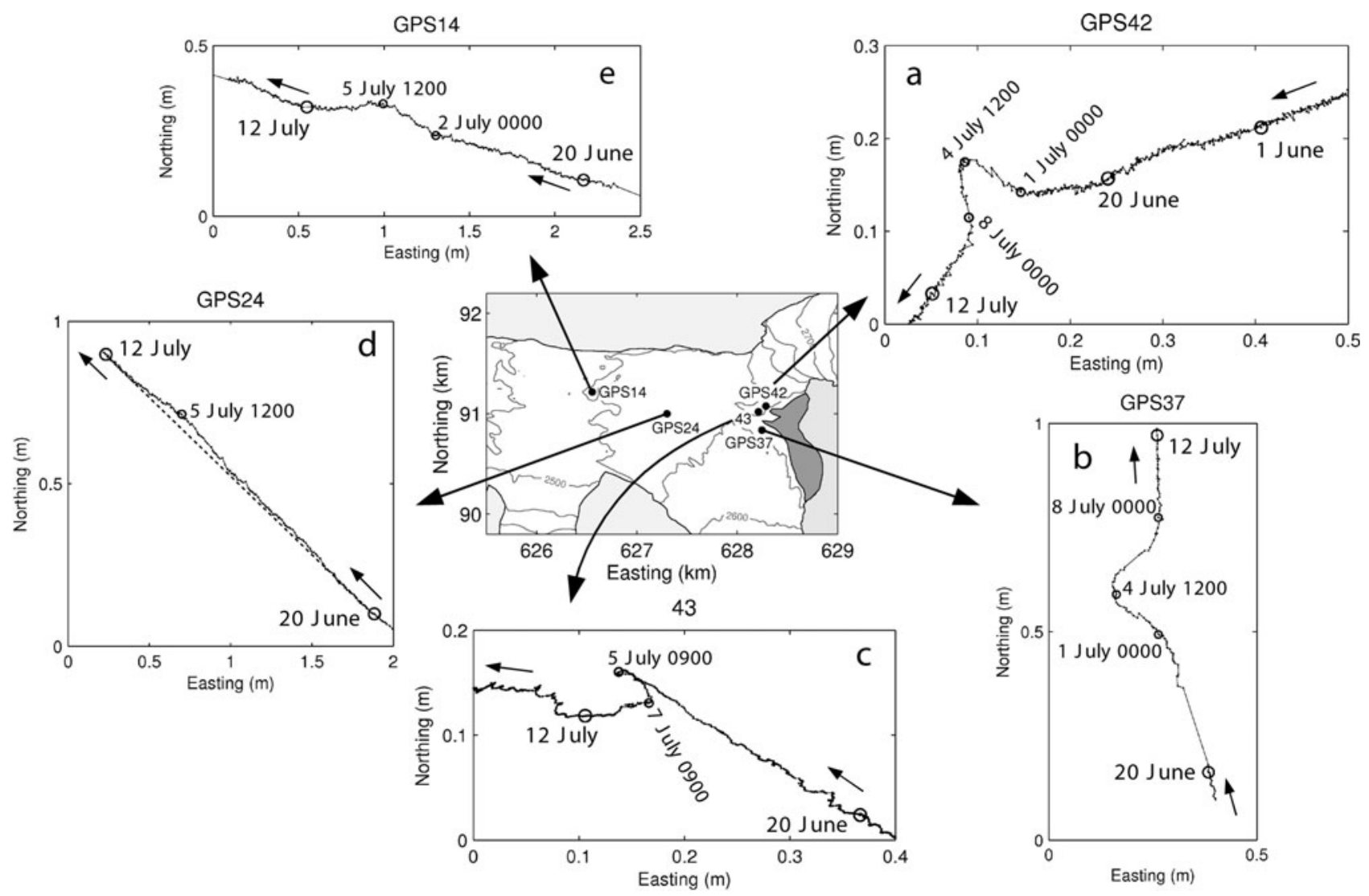

Fig. 5. Plan view of the stake motion at each survey site. The contour lines on the map indicate the surface elevation at intervals of $50 \mathrm{~m}$. The vertical axes in (d) and (e) are exaggerated by a factor of two to emphasize the transverse stake motion. The dotted line in (d) connects the stake positions at $0000 \mathrm{~h}$ on 20 June and 12 July.

Similar ice motion was observed at GPS37 (Fig. 5b). The trajectory of the stake movement deviated west from the preevent flow direction during the outburst. The changes in the flow direction occurred not only near the lake but also at GPS24 and GPS14 at reaches several kilometers below the lake. This deviation is not as evident as those at GPS37 and GPS42 because the flow speed is relatively high in the lower reaches; however, the stake moved away from the azimuth of the motion towards the northeast at GPS24 (Fig. 5d) and towards the north at GPS14 (Fig. 5e). The change in transverse velocity and the subsequent switch back to the azimuth of the initial motion are similar to the flow variations observed at Hansbreen during a speed-up event triggered by enhanced snowmelt (Vieli and others, 2004). The most intriguing ice motion was observed at stake 43 (Fig. 5c). The ice flowed northwest until the morning of 5 July; it then started to flow backward towards the southeast for about 2 days. This observation of a glacier flowing up-glacier is very unusual. The time of the reversal in the transverse ice motion is 4 July near the lake at GPS42 and GPS37 and about 1 day later down-glacier at GPS14 and GPS24.

\section{INTERPRETATION AND DISCUSSION}

The flow-speed increase and the surface uplift are probably caused by the subglacially drained lake water. Because the borehole water level was very high from 2 to 6 July (Fig. 3d), the pressurized subglacial water enhanced the basal ice motion and the surface flow speed increased. The uplift can be attributed to the water storage underneath the glacier, which occurred as a result of the time lag between the discharge peaks from the lake and the glacier (Fig. $3 \mathrm{c}$ and b). The magnitude and the timing of the uplift is similar to the observation on Kennicott Glacier during the drainage of Hidden Creek Lake (Anderson and others, 2005). The correlations of the peaks in the flow speed, uplift rate and water level are as expected from previously reported field observations and numerical investigations (Iken, 1981; Iken and others, 1983; Sugiyama and Gudmundsson, 2004). An unexpected observation was the reversal of ice motion characterized by the flow-direction changes at the onset, during and after the outburst, which correspond to the changes on 1, 4 and 8 July in the case of GPS42 and GPS37 (Fig. 5a and b).

During the first half of the lake outburst, the glacier motion became more parallel to the northwest ice flow at the central part of the confluence area, as described in the previous section (Fig. 4). Since the ice is thick at this part of the glacier, the most plausible interpretation of the flow change is that an accelerated central glacier flow pulled or pushed the surrounding ice by longitudinal stress coupling. For example, the change in the flow direction from the north to the northwest on 1 July at GPS37 (Fig. 5b) can be attributed to the dragging of the ice by the longitudinal stress transmitted from the accelerated northwest ice flow at the center of the glacier. Although the first change in the flow direction can be explained in this way, the second and the third changes are still unclear. If the glacier flow field had been influenced by the drained lake water, it should have returned to the pre-event pattern subsequently without 


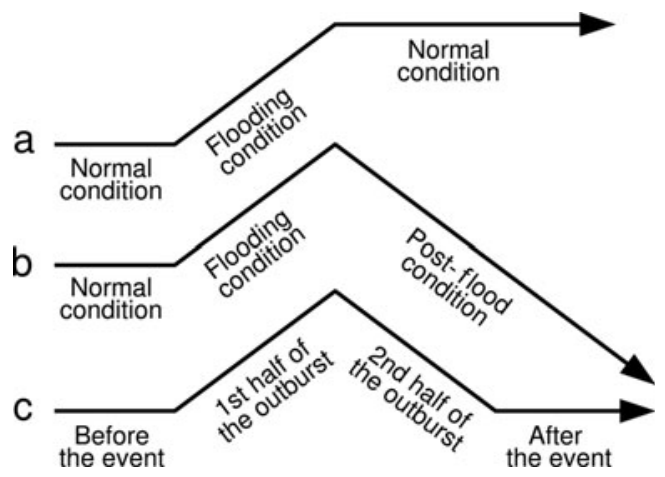

Fig. 6. Schematic diagrams showing the trajectories of stake motion during the lake outburst.

switching back to the azimuth of the original motion (Fig. 6a). Even if the flow conditions before and after the event were different, the flow direction should not have returned to the pre-event direction after the outburst (Fig. 6b). Hereafter, we focus on the interpretation of the observed reversal of ice motion, which is sketched in Figure 6c.

\section{The timing of the flow-direction changes}

To reveal the mechanism of the reversal of ice motion, the timings of flow-direction changes are analyzed by plotting the daily locations of GPS42 (Fig. 7a). A smooth trajectory was obtained from the GPS positioning data by kernel regression smoothing. We define the flow component perpendicular to the average flow vector from 20 June to 12 July as transverse ice motion. The transverse motion from 29 June to 9 July is examined by comparing it with the available lake discharge data and vertical surface motion (Fig. 7b and c).

First, the transverse motion had begun several days before the onset of the discharge (see also Fig. 5a), suggesting the influence of the lake water on the subglacial conditions before the outburst event. It is inferred from the sudden drop in the lake level on 1 July that lake water had already connected to some part of the ice-bed interface under the ice dam. A relatively small change in the basal condition before the outburst had enough influence on the ice motion to initiate the flow-direction change. Second, the rate of the northwest transverse motion was greatest on 2 July, when the water discharge was increasing, but not when the discharge was at the maximum level (Fig. $7 a$ and b). When the discharge was maximum at midnight from 3 to 4 July, the transverse velocity had decreased to nearly zero. The transverse flow component reversed from the northwest to the southeast at noon on 4 July, coinciding with the significant drop in discharge from the maximum level. These features show that the rate of transverse motion was related to the changing rate of lake discharge. It is likely that the direction of the transverse motion was determined by whether the discharge was increasing or decreasing: the ice flowed northwest or southeast when the discharge was increasing or decreasing, respectively. Third, the transverse motion and its reversal were correlated with the surface vertical motion (Fig. 7a and c). The surface rose up during the lake outburst, showing the uplift peak at nearly the same time as the reversal in the transverse flow component. The surface vertical motion appears to be related also to the lake discharge (Fig. $7 \mathrm{~b}$ and $\mathrm{c}$ ).
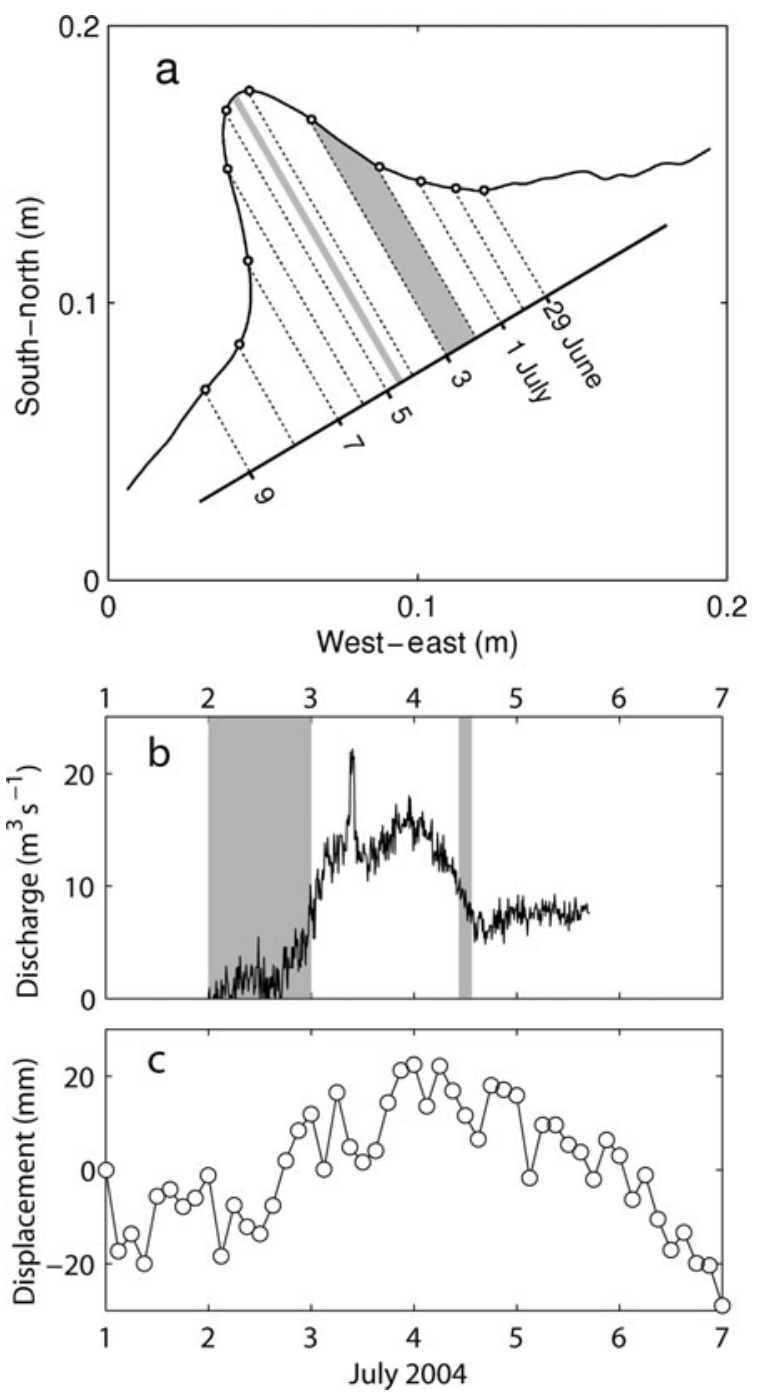

Fig. 7. (a) Plan view of the stake motion at GPS42. The open circles on the smoothed trajectory indicate the locations of the stake at $0000 \mathrm{~h}$. (b) Water discharge from the lake. The shaded bands show the day of the maximum northwest displacement and the timing of the reversal of the transverse ice motion. (c) Vertical displacement at GPS42 relative to the elevation at $0000 \mathrm{~h}$ on 1 July.

These features of the stake motion at GPS42 suggest several processes which may have caused the observed ice motion. Although a conclusive interpretation is not reached, possible mechanisms of the reversal of ice motion are discussed below.

\section{Viscoelastic ice deformation}

As implied by the surface uplift peak at the same time as the lake discharge, the magnitude of the discharge is presumably related to the basal decoupling and flow-speed increase in the region. If we take the discharge as the measure of the stress perturbation exerted by the accelerated central part of the glacier, the northwest and southeast ice motion at GPS42 appear to be driven by the increase and decrease in the stress perturbation, respectively. These observations lead us to suggest elastic glacier motion and its rebound as possible mechanisms of the reversal of ice motion. For example, at GPS42, if the northwest ice movement is an elastic response to the increasing longitudinal stress perturbation, the subsequent south movement is explained as its rebound, 


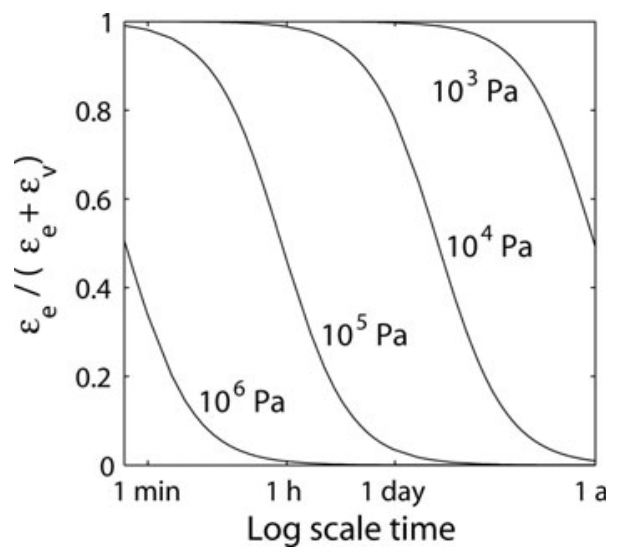

Fig. 8. Ratio of elastic to total strain under various stresses $(\tau)$, as calculated by Equation (1).

caused by the stress reverting to the pre-event condition. The maximum rate of the northwest motion coinciding with the increasing lake discharge and the reversal of the motion at the time of the discharge reduction are in agreement with the characteristic feature of elastic motion.

It is not surprising to observe elastic behavior in glacier motion since ice is a viscoelastic material. When an englacial stress field changes rapidly, elastic ice deformation is significant, and it recovers when the stress perturbation disappears. In fact, the tidal flexure of ice shelves (Vaughan, 1995) and tidal effects on an ice stream near the grounding line (Anandakrishnan and Alley, 1997) have been well explained by considering ice as an elastic material. Nevertheless, the relative importance of viscous and elastic components in the deformation of a viscoelastic material is dependent on the stress magnitude and temporal scale. This needs to be examined if the $\sim 100 \%$ recovery of the displacement observed over a period of 5-10 days is to be explained by the viscoelastic nature of ice.

The importance of elastic strain in total ice deformation was estimated using linear elasticity and Glen's viscous flow law with a stress exponent of 3. For simplicity, onedimensional stress and strain were considered, assuming a linear combination of elastic and viscous components. When a constant stress, $\tau$, is applied to initially stress-free ice for a time $t$, the proportion of elastic strain is

$$
\frac{\varepsilon_{\mathrm{e}}}{\varepsilon_{\mathrm{e}}+\varepsilon_{\mathrm{v}}}=\frac{\tau / E}{\tau / E+A \tau^{3} t^{\prime}}
$$

where $\varepsilon_{\mathrm{e}}$ and $\varepsilon_{\mathrm{v}}$ are the elastic and viscous strain, respectively, $E$ is the Young's modulus and $A$ is the rate factor. We use $E=5.1 \times 10^{9} \mathrm{~Pa}$ (Jellinek and Brill, 1956), which lies within the range of values determined by laboratory studies (Vaughan, 1995), and $A=6.4 \times 10^{24} \mathrm{~Pa}^{-3} \mathrm{~s}^{-1}$, which is suggested for temperate ice (Paterson, 1994). The elastic property of glacier ice does not differ significantly from that of artificial ice (Gammon and others, 1983), and the effects of temperature and pressure on the Young's modulus are very small under the conditions at Gornergletscher (Dantl, 1969; Gagnon and others, 1988). Plots of Equation (1) for various stresses show that almost the entire portion of the total strain can be attributed to elasticity only when the stress is less than $10^{3} \mathrm{~Pa}$ under the considered timescale of 5-10 days (Fig. 8). However, the stress required to produce $0.1 \mathrm{~m}$ of elastic ice deformation over a distance of $0.1-1 \mathrm{~km}$ (the vertical and horizontal length scales, respectively, of the studied area) is $\sim 10^{5}-10^{6} \mathrm{~Pa}$. The proportion of elastic strain is even smaller than shown in Figure 8 because the effect of initial stress and three-dimensional stress components on the non-linear viscosity of ice is neglected. Although the above estimation relies on a simplified rheology and stress-strain regime, it appears to be difficult to attribute the entire observed glacier motion to ice elasticity.

\section{Basal separation due to pressurized water}

The correlation between transverse ice motion and surface uplift suggests that the reversal of ice motion was associated with basal separation beneath the glacier. When the lake discharge rapidly increases, subglacial water pressure exceeds ice overburden pressure and lifts the glacier sole. The separation of the glacier sole in the direction normal to the inclined bed should produce horizontal as well as vertical ice motion. Such an effect at the lee side of a subglacial bump is the manifestation of a hydraulic jacking mechanism (Röthlisberger and Iken, 1981). Since the bedrock beneath Gornersee is inclined towards the west, this effect can explain the westward motion at GPS37 and GPS42. The magnitude of the separation increases when the discharge is rising, as implied by the correlation between surface uplift and discharge. When the separation reduces owing to the drop in discharge, the horizontal ice motion possibly reverses its direction. In addition to the basal separation, volume changes of subglacial sediments due to water-pressure variations exert a bed-normal force (Truffer and others, 2001). The stake motion at GPS42 from 1 to 4 July shows that the horizontal displacement was $\sim 60 \mathrm{~mm}$ northwest while the vertical displacement was $\sim 30 \mathrm{~mm}$ (Fig. 7a and c). Taking the annual mean vertical speed $\left(-4.6 \mathrm{~mm} \mathrm{~d}^{-1}\right)$ into consideration, $44 \mathrm{~mm}$ of vertical displacement may be attributed to the bed separation. Because the bed slope beneath Gornersee is approximately 0.5 towards the west (Iken and others, 1996; Huss, 2005), the horizontal component of the bed-normal ice motion $(44 \mathrm{~mm} \times 0.5=22 \mathrm{~mm})$ accounts for about $35 \%$ of the observed horizontal motion. If the water penetrated beneath the glacier, prying off the ice near the lake, the horizontal ice motion away from the lake would be larger than this estimation.

In the lower reaches, away from the lake, the northward ice motion at GPS14 and GPS24 seems to be difficult to explain by basal separation. However, if the subglacial pressure is elevated locally at a drainage conduit along the glacier center, surface uplift would be accompanied by horizontal motion towards the glacier margins. Such ice motion is expected by analogy of vertical and horizontal ground surface displacements due to the changes in the pressure exerted by the intrusion of magma (e.g. Mogi, 1958; Walsh and Decker, 1971). If this was the case, it is also possible that the flow-direction changes near the lake were influenced by the location and direction of the lake water intrusion into the bed. The viscoelastic property of ice presumably played an important role in the short-term glacier response to the basal separation and subsequent pressure drop.

\section{Subglacial sediment deformation}

Ice sliding over bedrock and subglacial sediment deformation are crucial in glacier motion. Because these processes are mostly controlled by basal stress and subglacial water 
pressure, they possibly play an important role in the reversal of ice motion. The basal sliding speed is usually formulated by a power function of the basal shear stress and the effective pressure (e.g. Weertman, 1957; Fowler, 1981; Bindschadler, 1983); thus, the sliding displacement would not recover when the magnitude of the stress or water pressure changes. The elastic behavior of subglacial sediment has been observed by tilt-sensor measurements conducted under glaciers (Iverson and others, 1995; Fischer and Clarke, 2001; Porter and Murray, 2001). In these measurements, tilt sensors installed in a subglacial sediment layer periodically showed up-glacier rotation, suggesting recovery of the elastic part of the deformation. Iverson and others (1999) tested subglacial sediment collected from Storglaciären, Sweden; these tests yielded a Young's modulus of 1.0-1.8 $\times 10^{6} \mathrm{~Pa}$. Assuming this value, the shear deformation of a $10 \mathrm{~m}$ thick sediment layer by a stress of $10^{4} \mathrm{~Pa}$ results in $\sim 0.1 \mathrm{~m}$ horizontal displacement. At Gornergletscher, although it has not been confirmed, the existence of a subglacial sediment layer up to $50 \mathrm{~m}$ thick was suggested by drilling and seismic measurements (Bezinge and others, 1973). It is debatable whether the subglacial motion can be transferred directly to the surface through an ice layer that is several hundred meters thick; however, sediment deformation has the potential to respond elastically to basal condition changes. A drawback of this interpretation is that the timing of the reported strain recovery in the sediment layer is not consistent with our measurements. The up-glacier rotation of the tilt sensor occurred when the glacier sole decoupled from the bed owing to increasing water pressure (Iverson and others, 1995; Fischer and Clarke, 2001), whereas in Gornergletscher the surface motion reversed when the lake discharge decreased.

\section{CONCLUSIONS}

In order to study the impact of the sudden drainage of a glacier-dammed lake on glacier dynamics, high-frequency ice-flow measurements were carried out with hydrological observations at Gornergletscher. During the outburst event of Gornersee in July 2004, the flow speed increased by $50 \%$ and the surface rose by $20 \mathrm{~cm}$; these changes were triggered by $4 \times 10^{6} \mathrm{~m}^{3}$ of water draining from the lake within 5 days. The borehole water level was consistently high near the flotation level, suggesting that the elevated subglacial water pressure enhanced the basal ice motion and the subglacial water cavity formation.

The most intriguing observation was that of the reversal of ice motion, including the $180^{\circ}$ backward ice flow recorded at one of the survey stakes. The flow-direction change can be attributed to stress coupling with accelerated ice flow at the central part of the glacier, but its reversal is difficult to explain. Detailed analysis of the ice motion shows that the rate of the transverse flow was correlated with the changing rate of lake discharge and the surface uplift rate. This analysis and the timescale of the event suggest that the elastic glacier response to the rapidly changing stress conditions and its rebound assume an important role. Nevertheless, the Young's modulus of ice is too large to explain the observed recovery of almost the entire transverse motion. Alternatively, the separation of the glacier sole from the inclined bed due to elevated water pressure may have caused the observed transverse ice motion. Subglacial sediment deformation can also cause complex glacier responses to changing basal conditions. It is difficult to provide a complete explanation of what we observed, based on the current knowledge of these processes and available data. Further study of the subglacial drainage pattern and viscoelastic property of the glacier is needed to verify the hypotheses.

Since the reversal of ice motion was observed in the vicinity of the lake on the ice dam, it possibly played a key role in the triggering and drainage mechanisms of the outburst. Moreover, the reversal was observed as being pervasive, from the lake vicinity to several kilometers lower, implying that the phenomenon commonly occurs under the influence of changing stress conditions. Thus, similar ice motion is expected during glacial events such as glacier surge, calving and stick-slip glacier motion (Fischer and Clarke, 1997; Bindschadler and others, 2003). Our study maintains that the response of a glacier to these events may not be explained by our current understanding of glacier mechanics; thus, further investigation of glacier motion under rapidly changing stress conditions is required.

\section{ACKNOWLEDGEMENTS}

We thank the members of the field campaign at Gornergletscher in 2004. Special thanks are due to B. Müller, M. Huss, U.H. Fischer and T. Wyder for their contribution to the field measurements. The river discharge data were kindly provided by Grande Dixence SA. The quality of the paper was substantially improved by careful reviews by J.S. Walder (scientific editor), M. Truffer and S. Anandakrishnan. The interpretation of the observed ice motion is indebted to the discussion with the editor and the referees. R. Greve and $\mathrm{H}$. Blatter provided helpful comments on the manuscript. This research was funded by Swiss National Science Foundation grant No. 200021-103882/1.

\section{REFERENCES}

Anandakrishnan, S. and R.B. Alley. 1997. Tidal forcing of basal seismicity of Ice Stream C, West Antarctica, observed far inland. J. Geophys. Res., 102(B7), 15,183-15,196.

Anderson, R.S., J.S. Walder, S.P. Anderson, D.C. Trabant and A.G. Fountain. 2005. The dynamic response of Kennicott Glacier, Alaska, USA, to the Hidden Creek Lake outburst flood. Ann. Glaciol., 40, 237-242.

Anderson, S.P. and 6 others. 2003. Integrated hydrologic and hydrochemical observations of Hidden Creek Lake jökulhlaups, Kennicott Glacier, Alaska. J. Geophys. Res., 108(F1), 6003. (10.1029/2002JF000004.).

Bezinge, A., J.P. Perreten and F. Schafer. 1973. Phénomènes du lac glaciaire du Gorner. IASH Publ. 95 (Symposium at Cambridge 1969 - Hydrology of Glaciers), 65-78.

Bindschadler, R. 1983. The importance of pressurized subglacial water in separation and sliding at the glacier bed. J. Glaciol., 29(101), 3-19.

Bindschadler, R.A., M.A. King, R.B. Alley, S. Anandakrishnan and L. Padman. 2003. Tidally controlled stick-slip discharge of a West Antarctic ice stream. Science, 301(5636), 1087-1089.

Collins, D.N. 1989. Seasonal development of subglacial drainage and suspended sediment delivery to melt waters beneath an Alpine glacier. Ann. Glaciol., 13, 45-50.

Dantl, G. 1969. Elastic moduli of ice. In Riehl, N., B. Bullemer and $\mathrm{H}$. Engelhardt, eds. Physics of ice: Proceedings of the International Symposium on Physics of Ice, Munich, Germany, September 9-14, 1968. New York, Plenum Publishing Corp., 223-230. 
Engelhardt, H. and B. Kamb. 1998. Basal sliding of Ice Stream B, West Antarctica. J. Glaciol., 44(147), 223-230.

Fischer, U.H. and G.K.C. Clarke. 1997. Stick-slip sliding behaviour at the base of a glacier. Ann. Glaciol., 24, 390-396.

Fischer, U.H. and G.K.C. Clarke. 2001. Review of subglacial hydromechanical coupling: Trapridge Glacier, Yukon Territory, Canada. Quat. Int., 86(1), 29-43.

Fowler, A.C. 1981. A theoretical treatment of the sliding of glaciers in the absence of cavitation. Philos. Trans. R. Soc. London, Ser. A, 298(1445), 637-681.

Gagnon, R.E., H. Kiefte, M.J. Clouter and E. Whalley. 1988. Pressure dependence of the elastic constants of ice Ih to $0-2.8$ kbar by Brillouin spectroscopy. J. Chem. Phys., 89(8), 4522-4528.

Gammon, P.H., H. Kiefte, M.J. Clouter and W.W. Denner. 1983. Elastic constants of artificial and natural ice samples by Brillouin spectroscopy. J. Glaciol., 29(103), 433-460.

Gudmundsson, G.H., A. Bassi, M. Vonmoos, A. Bauder, U.H. Fischer and M. Funk. 2000. High-resolution measurements of spatial and temporal variations in surface velocities of Unteraargletscher, Bernese Alps, Switzerland. Ann. Glaciol., 31, 63-68.

Huss, M. 2005. Gornergletscher: Gletscherseeausbrüche und Massenbilanzabschätzungen. (Diplomarbeit, ETH Zürich.)

Huss, M., A. Bauder, M. Werder, M. Funk and R. Hock. 2007. Glacier-dammed lake outburst events of Gornersee, Switzerland. J. Glaciol., 53(181). In press.

Iken, A. 1981. The effect of the subglacial water pressure on the sliding velocity of a glacier in an idealized numerical model. J. Glaciol., 27(97), 407-421.

Iken, A. and R.A. Bindschadler. 1986. Combined measurements of subglacial water pressure and surface velocity of Findelengletscher, Switzerland: conclusions about drainage system and sliding mechanism. J. Glaciol., 32(110), 101-119.

Iken, A., H. Röthlisberger, A. Flotron and W. Haeberli. 1983. The uplift of Unteraargletscher at the beginning of the melt season a consequence of water storage at the bed? J. Glaciol., 29(101), 28-47.

Iken, A., K. Fabri and M. Funk. 1996. Water storage and subglacial drainage conditions inferred from borehole measurements on Gornergletscher, Valais, Switzerland. J. Glaciol., 42(141), 233-248.

Iverson, N.R., B. Hanson, R.LeB. Hooke and P. Jansson. 1995. Flow mechanism of glaciers on soft beds. Science, 267(5194), 80-81.

Iverson, N.R., R.W. Baker, R.LeB. Hooke, B. Hanson and P. Jansson. 1999. Coupling between a glacier and a soft bed. I. A relation between effective pressure and local shear stress determined from till elasticity. J. Glaciol., 45(149), 31-40.

Jansson, P. 1995. Water pressure and basal sliding on Storglaciären, northern Sweden. J. Glaciol., 41(138), 232-240.

Jellinek, H.H.G. and R. Brill. 1956. Viscoelastic properties of ice. J. Appl. Phys., 27(10), 1198-1209.

Kamb, B. 2001. Basal zone of the West Antarctic ice streams and its role in lubrication of their rapid motion. In Alley, R.B. and
R.A. Bindschadler, eds. The West Antarctic ice sheet: behavior and environment. Washington, DC, American Geophysical Union, 157-199. (Antarctic Research Series 77.)

Mogi, K. 1958. Relations between the eruption of various volcanoes and the deformations of the ground surfaces around them. Bull. Earthquake Res. Inst., 36, 99-134.

Naruse, R., H. Fukami and M. Aniya. 1992. Short-term variations in flow velocity of Glaciar Soler, Patagonia, Chile. J. Glaciol., 38(128), 152-156.

Paterson, W.S.B. 1994. The physics of glaciers. Third edition. Oxford, etc., Elsevier.

Porter, P.R. and T. Murray. 2001. Mechanical and hydraulic properties of till beneath Bakaninbreen, Svalbard. J. Glaciol., 47(157), 167-175.

Raymond, M., M. Wegmann and M. Funk. 2003. Inventar gefährlicher Gletscher in der Schweiz. Mitt. VAW ETH 182

Roberts, M.J. and 10 others. 2005. Large increase in glacier sliding during subglacial flooding. Geophys. Res. Abstr., 7, 09946. (European Geosciences Union General Assembly 2005, 24-29 April 2005, Vienna, Austria.) (1607-7962/gra/ EGU05-A-09946.)

Röthlisberger, H. and A. Iken. 1981. Plucking as an effect of waterpressure variations at the glacier bed. Ann. Glaciol., 2, 57-62.

Röthlisberger, H., A. Iken and U. Spring. 1979. Piezometric observations of water pressure at the bed of Swiss glaciers. J. Glaciol., 23(89), 429-430.

Seifert, B., M. Brockmann, J. Engel and T. Gasser. 1994. Fast algorithms for nonparametric curve estimation. J. Comput. Graph. Stat., 3(2), 192-213.

Sugiyama, S. and G.H. Gudmundsson. 2003. Short-term variations in glacier flow controlled by subglacial water pressure at Lauteraargletscher, Bernese Alps, Switzerland. J. Glaciol., 50(170), 353-362.

Truffer, M., K.A. Echelmeyer and W.D. Harrison. 2001. Implications of till deformation on glacier dynamics. J. Glaciol., 47(156), 123-134.

Vaughan, D.G. 1995. Tidal flexure at ice shelf margins. J. Geophys. Res., 100(B4), 6213-6224.

Vieli, A., J. Jania, H. Blatter and M. Funk. 2004. Short-term velocity variations on Hansbreen, a tidewater glacier in Spitsbergen. J. Glaciol., 50(170), 389-398.

Walder, J.S. and 6 others. 2005. Fault-dominated deformation in an ice dam during annual filling and drainage of a marginal lake. Ann. Glaciol., 40, 174-178.

Walder, J.S. and 6 others. 2006. Local response of a glacier to annual filling and drainage of an ice-marginal lake. J. Glaciol., 52(178), 440-450.

Walsh, J.B. and R.W. Decker. 1971. Surface deformation associated with volcanism. J. Geophys. Res., 76(14), 3291-3302.

Weertman, J. 1957. On the sliding of glaciers. J. Glaciol., 3(21), 33-38.

Weiss, P. 2005. Gletscherdynamik vor und nach der Entleerung des Gornersees im Sommer 2004. (Diplomarbeit, ETH Zürich.) 